\title{
ОЦІНЮВАННЯ ФІТОСАНІТАРНОГО СТАНУ ДЕРЕВНИХ НАСАДЖЕНЬ ЛАНДШАФТНОЇ ДІЛЯНКИ "СХІДНА БАЛКА" ДЕНДРОПАРКУ "ОЛЕКСАНДРІЯ" НАН УКРАЇНИ
}

Визначено фітосанітарний стан деревних рослин Східної балки дендрологічного парку "Олександрія" в межах наукової теми "Відновлення та реконструкція історичних ландшафтних ділянок рівнинно-балкового типу в Державному дендрологічному парку "Олександрія" НАН України". Ураження хворобами і шкідниками виявлено на 331 екз. (36,8 \% від загальної кількості) деревних рослинах, що належать до 19 видів. Описано основні хвороби і ураження шкідниками у дерев. Розвиток хвороб на деревах та їх фітосанітарний стан визначено за фітоценотичними умовами та екологічними умовами мезорельєфу. Більшість хвороб у деревних рослин протікала в хронічній формі, не призводячи до втрати декоративності дерева і до ослаблення його життєздатності. Гострий характер спричинило короїдне всихання сосни зі супутньою синявою та всихання Fraxinus excelsior L. із симптомокомплексом ознак, характерних для хвороби Chalara fraxinea. Ці ураження призводять до стрімкого всихання дерев, розпаду ландшафтних композицій. Під час планування оптимізації насаджень ділянки "Східної балки" потрібно враховувати фітопатологічний стан дерев, прогнозувати їх відпад, проводити заходи з індивідуального лікування і догляду дерев, профілактичні і захисні заходи.

Ключові слова: відновлення ландшафтних територій; хвороби; шкідники; швидке всихання; хронічне всихання.

Вступ. Відновлення ділянок старовинних ландшафтних парків є важливою складовою частиною роботи дендропарків, які стали їх спадкоємцями. Основою під час формування садово-паркових композицій є створення довговічних і біологічно стійких насаджень. Присадибні парки формувалися переважно на базі наявних лісових насаджень, тому за оптимізації паркових ландшафтів потрібно оцінити фітосанітарний стан і декоративні якості цих насаджень, щоб зберегти природний характер і природні особливості ділянки.

Збереженню та відновленню паркових композицій приділено значну увагу в роботах провідного українського дендролога М. А. Кохна (Klimenko \& Kuznetsov, 2014). Важливими для розуміння теорії та практики садово-паркового будівництва та використання рослин у ландшафтних композиціях $є$ роботи Ю. О. Клименко і С. І. Кузнєцова (Klimenko, 2012; Kohno \& Pasechnyiy, 1981).

Мета роботи - визначити фітосанітарний стан деревних рослин Східної балки дендрологічного парку "Олександрія" в межах наукової теми "Відновлення та реконструкція історичних ландшафтних ділянок рівнинно-балкового типу в Державному дендрологічному парку "Олександрія" НАН України".

Матеріали і методика дослідження. Об'єкт дослі- джень - деревні рослини Східної балки дендропарку "Олександрія". Інвентаризацію деревних насаджень здійснювали під час натурних обстежень та польових маршрутних досліджень (Selochnik \& Kondrashova, 1989). Діагностику хвороб проводили за зовнішніми макроскопічними ознаками (наявністю плодових тіл, ракових ран, дупел, суховерхівковості, виразок, розпад тканин, наявність на деревах нальотів, грибниці, плівок міцелію, плодових тіл тощо) (Zhuravlev, 1962; Stark, 1932). Обстеження деревних насаджень на наявність стовбурових шкідників проводили згідно з методичними рекомендаціями (Metodichni, 2010). Ознаки скритих гнилей встановлювали $\quad$ за I. І. Журавльовим (1962). Життєвий стан рослин визначали за шкалою категорій стану, прийнятою у лісовій патології (Sanitarni, 1995). Облік омели проводили ранньою весною та восени за 4 бальною шкалою, яка за рівнем ураження дерев поділяється на низький, середній, високий, дуже високий (Vasilenko \& Filippova, 2013).

Результати дослідження та їх обговорення. У районі Східної балки зростають деревні рослини 28 видів, зокрема 63 екз. 8 видів вікових дерев. Ураження хворобами і шкідниками виявлено на 331 екз. (36,8 \%) деревних рослинах, що належать до 19 видів (табл.).

Інформація про авторів:

Драган Ніна Вікторівна, канд. біол. наук, науковий співробітник. Email: ninapark@ukr.net Дойко Наталія Михайлівна, канд. біол. наук, ст. науковий співробітник. Email: nati2110@yandex.ru Мордатенко Ігор Леонідович, канд. біол. наук, науковий співробітник. Email: Mangust012@i.ua

Цитування за ДСту: Драган Н. В., Дойко Н. М., Мордатенко І. Л. Оцінювання фітосанітарного стану деревних насаджень ландшафтної ділянки "Східна балка" дендропарку "Олександрія" НАН України. Науковий вісник НлТУ України. 2018, т. 28, № 2. C. $45-49$.

Citation APA: Dragan, N. V., Dojko, N. M., \& Mordatenko, I. L. (2018). The Evaluation of a Phytosanitary State of Landscape tree Plantations of the "Eastern Ravine" of the "Alexandria" State Arboretum of the NAS of Ukraine. Scientific Bulletin of UNFU, 28(2), 45-49. https://doi.org/10.15421/40280207 
Табл. Види деревних рослин Східної балки, на яких виявлено ураження шкідниками і хворобами

\begin{tabular}{|c|c|c|c|c|c|c|c|c|}
\hline \multirow{2}{*}{$\begin{array}{l}\text { № } \\
3 / \Pi\end{array}$} & \multirow{2}{*}{ Назва рослини } & \multicolumn{7}{|c|}{ Вікові групи, років } \\
\hline & & 20 & 40 & 60 & 80 & 100 & 200 & $\sum$ \\
\hline 1 & Tilia cordata Mill. & 8 & 9 & 4 & 6 & 3 & - & 30 \\
\hline 2 & Acer campestre L. & 6 & 8 & 7 & 1 & & & 22 \\
\hline 3 & Acer platanoides L. & 18 & 27 & 11 & 4 & 4 & 1 & 65 \\
\hline 4 & Acer pseudoplatanus L. & - & & & & & 1 & 1 \\
\hline 5 & Fraxinus excelsior L. & 12 & 68 & 15 & 4 & 1 & 3 & 103 \\
\hline 6 & Ulmus scabra Mill. & 3 & 3 & 1 & 1 & - & 1 & 9 \\
\hline 7 & Robinia pseudoacacia L. & - & 11 & 5 & 2 & - & - & 18 \\
\hline 8 & Aesculus hippocastanum L. & 1 & 1 & 1 & 1 & 2 & - & 6 \\
\hline 29 & Carpinus betulus L. & $\begin{array}{lllll}- & \end{array}$ & 5 & 2 & - & 2 & - & 9 \\
\hline 10 & $\begin{array}{l}\text { Populus } x \text { canescens (Ait.) } \\
\text { Smith }\end{array}$ & - & - & 4 & - & - & - & 4 \\
\hline 11 & Larix decidua Mill. & - & - & - & - & - & 2 & 2 \\
\hline 12 & $\begin{array}{l}\text { Phellodendron amurense } \\
\text { Rupr. }\end{array}$ & - & - & - & 6 & - & - & 6 \\
\hline 13 & Rhus typhina L. & 3 & - & - & - & - & - & 3 \\
\hline 14 & Thuja occidentalis L. & - & 1 & - & - & - & - & 1 \\
\hline 15 & Betula pendula Roth & - & 1 & 2 & - & - & - & 3 \\
\hline 16 & Alnus glutinosa (L.) Gaerth & - & - & - & - & 1 & - & 1 \\
\hline 17 & Pinus sylvestris L. & - & - & - & - & - & 4 & 4 \\
\hline 18 & Quercus robur L. & - & - & 3 & - & - & 31 & 34 \\
\hline 19 & Picea abies L. (Karst.) & 3 & 2 & 3 & - & 2 & - & 10 \\
\hline & Всього & 54 & 136 & 58 & 25 & 15 & 43 & 331 \\
\hline
\end{tabular}

Fraxinus excelsior L.- 103 екз. (66,7 \% від загальної кількості) дерев на досліджуваній території уражені шкідниками та хворобами. Найбільше хворих рослин виявлено серед молодих і середньовікових дерев. У деяких рослин 20-60-річного віку виявлено інфекційний некроз кори, який спричиняється сумчастими і недосконалими грибами. Відбувається відмирання смуг кори i камбію. Після відмирання кори на деревах утворювалися тріщини, зріджувалася крона, окремі скелетні гілки.

Вікові дерева Fraxinus excelsior були уражені плодовими тілами трутовиків - справжнього (Foraes fomentarius (L.) Gill) і лускатого (Poliporus squarnosus Hudr. et Fr. Деякі дерева, починаючи з 40-річного віку, низькою і середньою мірою уражувалися омелою білою (Viscum album L.).

Досліджувана ділянка є осередком всихання Fraxinus excelsior 3 комплексом симптомів, властивих для небезпечної хвороби Chalara fraxinea (Davidenko, 2015; Kowalski, 2006). У дерев наявні характерні ураження листя і центральної жилки, некрози на корі гілок і стовбура, виразки, всихання пагонів, суховерхівковість (рис. 1). До 2016 р. локально, на площі близько 0,2 га, всохло 22 середньовікових дерева Fraxinus excelsior, ще на 48 деревах в цьому районі з'явилися описані симптоми ураження. Упродовж 2017 р. загинуло вже 75 дерев, а осередок всихання поширився в напрямку південної і центральної частин парку. Хвороба вразила й інші вікові групи - загинуло 5 дерев віком понад 150 років.

Acer platanoides. У дерев усіх вікових груп, що зростали в умовах ценотичного тиску, спостерігалося перевершинення, асиметрія і зрідження крони, суховерхівковість. Найбільше істотних хвороб виявлено на деревах 40-річного віку: локальні некрозо-ракові хвороби (зокрема, ступінчастий рак, який спричиняється грибами Nectria ditissima Tul., і Cylindrocarpon willkommii (Lind) Wr), гнилі, пухлини, виразки, морозобійні тріщини, омела. У дерев старшого віку - гнилі, які супроводжувалися плодовими тілами дереворуйнівних грибів, дупла, виразки (рис. 2). Алейне насадження 3 Acer platanoides по західній межі досліджуваної ділянки і різно- вікові куртини по схилам ставків високою і дуже високою мірою уражені омелою білою.

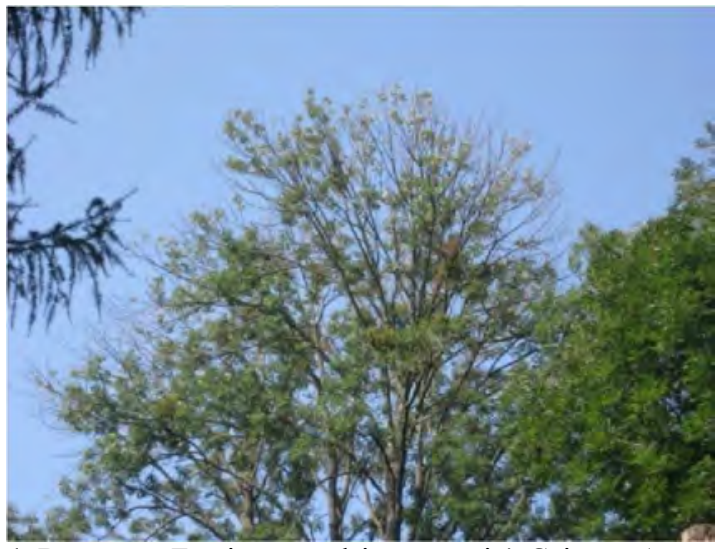

Рис. 1. Всихання Fraxinus excelsior у верхів'і Східної балки
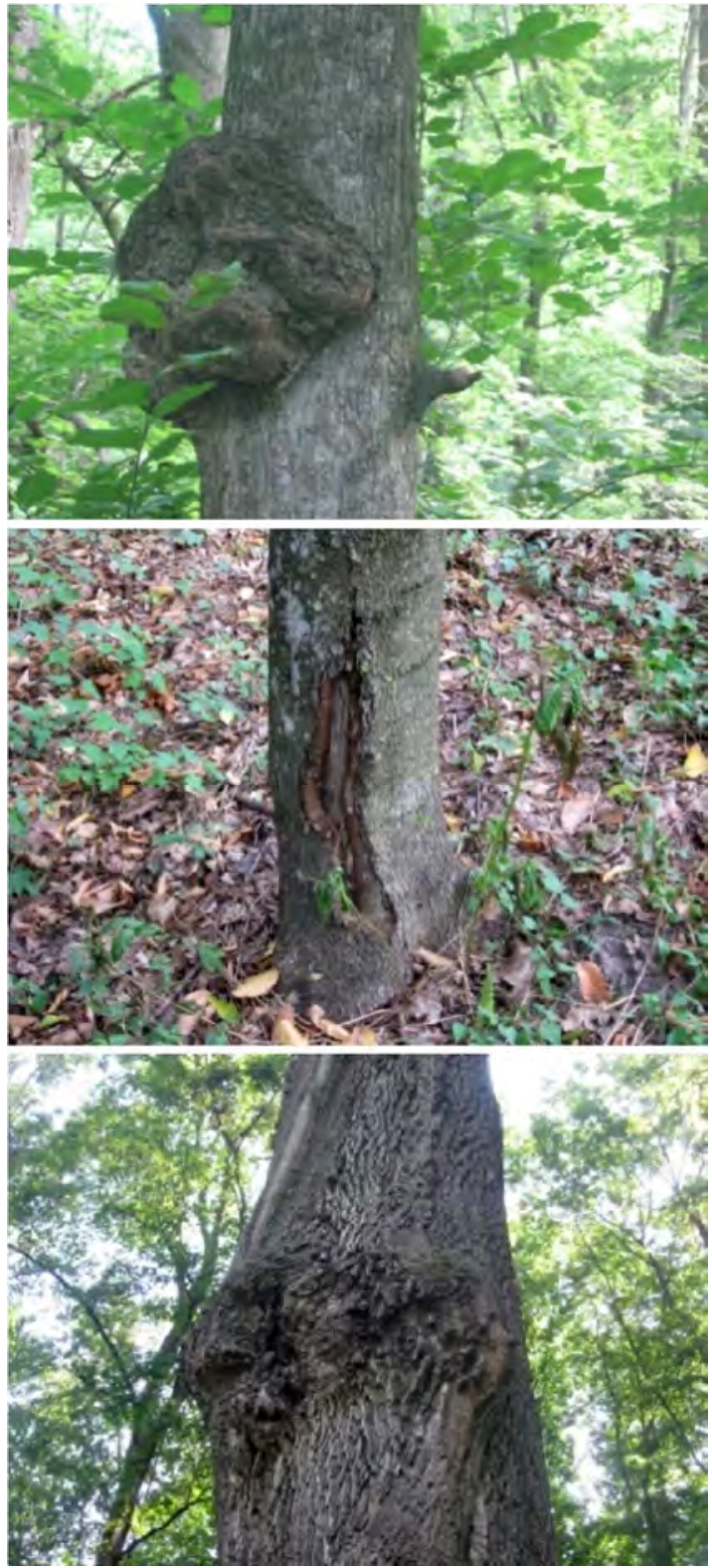

Рис. 2. Патологічні явища на деревах Acer platanoides

Tilia cordata. Найпоширенішими хворобами були зрідженість крони, суховерхівковість, грибкові ураження листя, всихання скелетних гілок. Починаючи з 20річного віку, у дерев траплялися гнилі і дупла. Зі 40річного віку на окремих деревах розвивалася омела (середньою мірою). Ступінчастий рак утворювався на де- 
ревах різних вікових груп. У дерев, старіших ніж 100 років, на стовбурі масово з'являлися нарости.

Acer campestre. У дерев наймолодшої вікової групи відбувалося зрідження крони, перевершинення, некрозо-ракові хвороби, всихання. 3 віком кількість дерев, уражених некрозо-раковими хворобами, ступінчастим раком, раковими виразками, зростала, з'являлися гнилі, дупла, морозобійні тріщини, ураження омелою (високою і дуже високою мірою). Починаючи з 60-річного віку, частка хворих дерев зменшувалася (вони гинули), на деяких деревах виявлено морозобійні тріщини, гнилі, дупла.

Robinia pseudoacacia. Кількість уражених дерев була невеликою - 18 екз., проте на рослинах спостерігалися істотні патології - всі дерева були вражені омелою високою і дуже високою мірою, з 40-річного віку з'являлася зрідженість крони, некрозо-ракові хвороби, гнилі, дупла, з 60-річного віку до перелічених хвороб додавалися виразки, суховерхівковість, нарости, трутовики, всихали сухі скелетні гілки.

Quercus robur - більшість старовікових дерев (24 екз. або 77,4 \%) належало до III категорії життєвого стану. Серед основних патологій виявлено суховерхівковість, зрідженість крони, всихання та обломи скелетних гілок, гнилі та їх остання стадія - дупла, плодові тіла дереворуйнівних грибів (Phellinusrobustus (Karst.) Bond. et Galz, Inonotus dryophilus (Berk) Murr, Inonotus dryadeus (Pers. ex Fr.) Murr, Laetiporus sulphureus (Bull.) Bond. et Sing, Inonotus dryaderus (Pers. et Fr.) Murr, Daedalea queroina (L.) Pers, Fistulina hepatica Fr. Stereum gausapatum Fr. Laetiporus sulphureus (Bull. et Fr.) Bond. et Sing та ін.; бактеріальна водянка дуба, поперечний рак дуба, грозобоїни і морозобійні тріщини.

Усі вікові дерева Quercus robur навіть 3 наявністю хвороб зберігали високу декоративність, величність і монументальність і можуть бути ключовими елементами під час створення нових композицій на досліджуваній ландшафтній ділянці.

Pinus sylvestris. 32017 р. на ландшафтній ділянці відбувається гостре всихання вікових дерев. Серед комплексу симптомів на деревах виявлено смоляні воронки, під корою ходи верхівкового короїда (Ips acuminatus Gyll.), його супутника шестизубого короїда (Ips sexdentatus Boern.). Територія навколо дерева усіяна зеленими гілочками сосни 3 ходами від шкідника. Спостерігається швидке ураження лубу і заболоні так званою "синявою" (рис. 3), що спричиняється групою офіостомових грибів (Zvyagintsev \& Sazonov, 2014). Ознаки ураження швидко розвиваються і призводять до всихання дерев. Аналогічний симптомокомплекс супроводжує масове всихання дерев сосни в Україні і за ії межами (Metodichni, 2010).

Інші види дерев, що зростають на обстеженій території, трапляються в невеликій кількості. На них здебільшого виявлено ті ж хвороби, що і на описаних вище видах рослин - некрозо-ракові рани, зрідженість крони, суховерхівковість (Phellodendron amurense, Ulmus scabra, Aesculus hippocastanum, Carpinus betulus, Betula pendula); на старовікових деревах Aesculus hippocastanum гнилі, дупла, плодові тіла дереворуйнівних грибів, на деревах Betula pendula - ознаки, характерні для бактеріальної водянки (Gvozdyak \& Yakovleva, 1979). У Phellodendron amurense, як реакція на засуху, спостерігалася фізіологічна реакція - недорозвиненість листових пластинок у верхівковій зоні.

Розвиток хвороб на деревах та їх фітосанітарний стан визначали за екологічними умовами мезорельєфу. Найбільше хвороб і найгірший фітосанітарний стан у дерев спостерігали по верхній лінії схилів та на підвищених рівнинних місцях, де, у умовах нестачі опадів, відчувався великий водний дефіцит. На дні балок, в нижніх частинах схилів, де завдяки чисельним джерельцям зволоження було достатнім, стан дерев був цілком задовільним, незважаючи на наявні там техногенні фітотоксиканти. До втрати декоративності, розвитку хвороб у молодих і середньовікових дерев призводило ценотичне пригнічення.

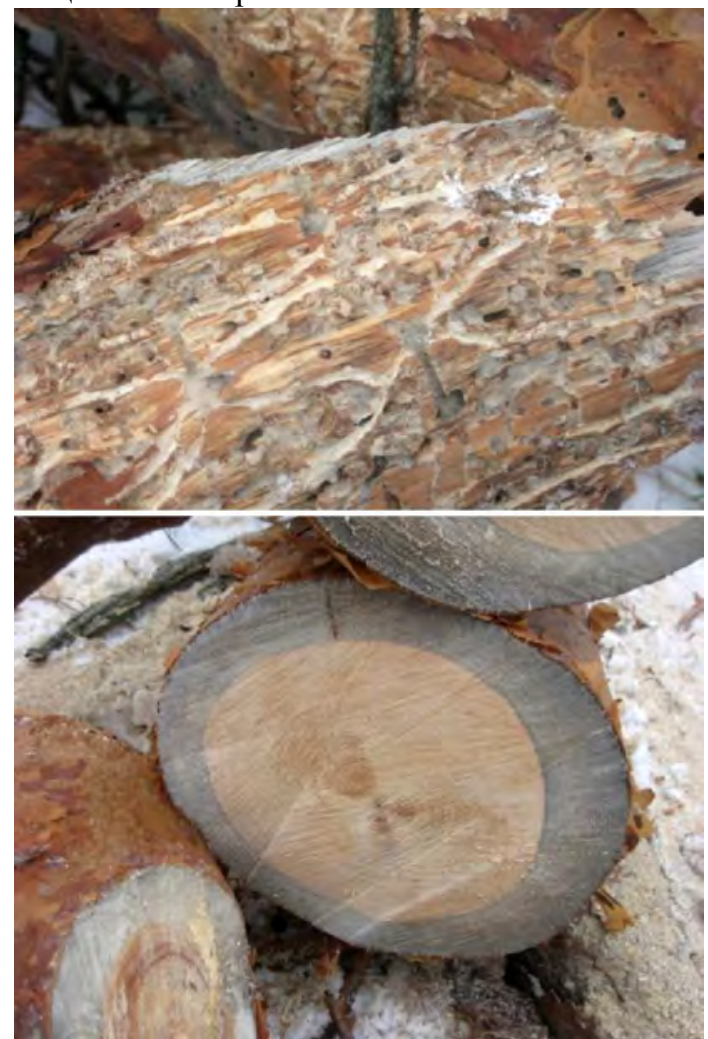

Pис. 3. Симптоми, що супроводжують всихання Pinus sylvestris

Більшість хвороб у деревних рослин протікала в хронічній формі, призводячи до втрати декоративності дерева і до ослаблення його життєздатності. Не призводили до різких негативних наслідків закриті морозобійні тріщини, невеликі рани від некрозо-ракових хвороб, заселення омелою, деякі дереворуйнівні гриби за незначного ураження і невеликих габітуальних проявів.

Гострий характер спричиняло короїдне всихання сосни з супутньою синявою та всихання Fraxinus excelsior iз симптомокомплексом ознак, характерних для хвороби Chalara fraxinea. Ці ураження в районі досліджень призводять до стрімкого масового всихання дерев, розпаду ландшафтних композицій. Ця проблема сьогодні має глобальний характер (Davidenko, 2015; Zvyagintsev \& Sazonov, 2014) і не існує ефективних заходів боротьби з цими фітопатогенами.

Під час планування оптимізації насадження Східної балки потрібно враховувати фітопатологічний стан дерев, прогнозувати їх відпад і утворення при цьому "вікон", здійснювати заходи з індивідуального лікування і догляду дерев, профілактичні і захисні заходи. 


\section{Висновки}

1. Хворобами і шкідниками в районі досліджень уражено 331 екз. (36,8 \% деревних рослин, які належать до 19 видів).

2. На деревних рослинах Східної балки виявлено низку хвороб та уражень від шкідників, які певною мірою шкодять рослинам.

3. Основна кількість хвороб і уражень шкідниками протікали хронічно. Гострий характер має короїдне всихання сосни зі супутньою синявою та всихання Fraxinus excelsior $з$ симптомокомплексом ознак, характерних для хвороби Chalara fraxinea.

4. Екологічні умови мезорельєфу значною мірою визначали фітосанітарний стан рослин.

5. Ураження омелою найбільшою мірою було в дерев, що зростали по схилах ставків і "розташовували" свої крони у вільному просторі.

6. Під час планування оптимізації насадження Східної балки потрібно враховувати фітопатологічний стан дерев, прогнозувати їх відпад і утворення при цьому "вікон".

\section{Перелік використаних джерел}

Davidenko, E. V. (2015). Osnovnyie prichinyi massovogo usyihaniya yasenya $\mathrm{v}$ tsentralnyih i vostochnyih oblastyah Ukrainyi. [The main causes of mass drying of ash in the central and eastern regions of Ukraine]. Izvestiya Sankt-Peterburgskoy lesotehnicheskoy akademii, 211, 147-160. [in Russian].

Gvozdyak, R. I., \& Yakovleva, L. M. (1979). Bakterialnyie bolezni lesnyih drevesnyih porod. [Bacterial diseases of forest tree species]. Kyiv. 64 p. [in Russian].

Klimenko, Yu. O. (2012). Ekologo-biologichni osnovi vidnovlennya starovinnih parkiv Polissya ta Lisostepu Ukrayini. Candidate Dissertation for Agricultural Sciences (06.03.01 - Forest crops and Phytomelioration). [Ecological and biological bases of restoration of old parks of the Polissya and the forest-steppe of Ukraine]. Lviv. 31 p. [in Ukrainian].

Klimenko, Yu. O., \& Kuznetsov, S. I. (2014). Kompleksna otsinka parkovih nasadzhen (metodichni pidhodi $i$ rekomendatsiyi)
[Comprehensive evaluation of parkings (methodological approaches and recommendations)]. Kyiv. $66 \mathrm{p}$. [in Ukrainian].

Kohno, N. A., \& Pasechnyiy, A. A. (1981). Printsipyi rekonstruktsii parkovyih nasazhdeniy s tselyu vosstanovleniya ih dekorativnyih kachestv v dendrologicheskih zapovednyih parkah Ukrainyi. [Principles of reconstruction of parks with the purpose of restoration of their decorative qualities in dendrological protected parks of Ukraine]. Vosstanovlenie i obogaschenie parkovyih landshaftov na Ukraine, 4, 3-7. Kyiv: Nauk. dumka. [in Ukrainian].

Kowalski, T. (2006). Chalara fraxinea sp. Nov. associated with dieback of ash (Fraxinus excelsior) in Poland. Forest Pathology, 36, 264-270. https://doi.org/10.1111/j.1439-0329.2006.00453.x

Metodichni. (2010). Metodichni rekomendatsiyi schodo obstezhennya oseredkIv stovburovih shkIdnikIv lIsu. [Comprehensive evaluation of parkings (methodological approaches and recommendations)]. Kharkov. 27 p. [in Ukrainian].

Sanitarni. (1995). Sanitarni pravilav lisah Ukrayini. [The sanitary rules of forests of Ukraine]. Kyiv. 19 p. [in Ukrainian].

Selochnik, N. N., \& Kondrashova, N. K. (1989). Obschaya otsenka sostoyaniya nasazhdeniy po dannyim rekognostsirovochnogo i detalnogo lesopatologicheskogo issledovaniy. [General estimation of the condition of plantations according to the data of reconnaissance and detailed forestry pathological researches]. Sostoyanie dubrav Lesostepi, (pp. 138-153). Moscow: Nauka.

Stark, V. N. (1932). Rukovodstvo po uch Yotu povrezhdeniy lesa (s opredeleniem). [Forest damage accounting manual (with definition)]. Moscow-Leningrad: Gos. izd-vo s.-h. i kolh.-koop. literaturyi. $408 \mathrm{p}$.

Vasilenko, I. D., \& Filippova, L. M. (2013). Borotba z omeloyu na topoli u zeleniy zoni Biloyi Tserkvi. [Fighting mistletoe on a poplar in the green zone of the Bila Tserkva]. Scientific Bulletin of UNFU, 23(12), 31-38. [in Ukrainian].

Zhuravlev, I. I. (1962). Diagnostika bolezney lesa. [Diagnosis of diseases of the forest]. Moscow. 142 p. [in Russian].

Zvyagintsev, V. B., \& Sazonov, A. A. (2014). Koroednoe usyihanie sosnyi (Pinus sylvestris L.) v lesah Belarusi. [Pine drying (Pinus sylvestris L.) in the forests of Belarus]. VIII chteniya pamyati O. A. Kataeva. Vrediteli i bolezni drevesnyih rasteniy Rossii. Materialyi mezhdunarodnoy konferentsii Sankt-Peterburg. 34 p. [in Russian].

Н. В. Драган, Н. М. Дойко, И. Л. Мордатенко

Государственный дендрологический парк "Александрия", НАН Украины, г. Белая Церковь, Украина

\section{ОЦЕНКА ФИТОСАНИТАРНОГО СОСТОЯНИЯ ДРЕВЕСНЫХ НАСАЖДЕНИЙ ЛАНДШАФТНОГО УЧАСТКА "ВОСТОЧНАЯ БАЛКА" ДЕНДРОПАРКА "АЛЕКСАНДРИЯ" НАН УКРАИНЫ}

Определено фитосанитарное состояние древесных растений Восточной балки дендрологического парка "Александрия" в рамках научной темы "Восстановление и реконструкция исторических ландшафтных участков равнинно-балочного типа в Государственном дендрологическом парке "Александрия" НАН Украины". Повреждения болезнями и вредителями выявлены на 331 экз. (36,8 \% от общего количества) древесных растений, принадлежащих к 19 видам. Описаны основные болезни и повреждения вредителями у деревьев. Развитие болезней на деревьях и их фитопатологическое состояние определены по фитоценотическим условиям и экологическим условиям мезорельефа. Большинство болезней у древесных растений протекала в хронической форме, не приводя к потере декоративности дерева и к ослаблению его жизнеспособности. Острый характер вызывало короедное усыхание Pinus sylvestris L. из сопутствующей синевой и усыхание Fraxinus excelsior L. из симптомокомплексом признаков, характерных для болезни Chalara fraxinea. Данные поражения приводили к стремительному усыханию деревьев, разрушению ландшафтных композиций. При планировании оптимизации насаждений участка "Восточная балка" необходимо учитывать фитопатологическое состояние деревьев, прогнозировать их отпад, проводить меры по индивидуальному лечению и уходу за деревьями, профилактические и защитные мероприятия.

Ключевые слова: восстановление ландшафтных зон; заболевания; вредители; быстрое усыхание; хроническое усыхание.

N. V. Dragan, N. M. Dojko, I. L. Mordatenko

State Dendrological Park "Olexandria", NAS Ukraine, Bila Tserkva, Ukraine

\section{THE EVALUATION OF A PHYTOSANITARY STATE OF LANDSCAPE TREE PLANTATIONS OF THE "EASTERN RAVINE" OF THE "ALEXANDRIA" STATE ARBORETUM OF THE NAS OF UKRAINE}

A restoration of the sites of ancient landscaping parks is an important part of the work of arboretums, which became their successors. The formation basis of the garden-park compositions is the creation of durable and biologically stable plantings. Therefore, the purpose of this work was to determine the phyto-sanitary state of woody plants of the Eastern Ravine at the "Alexandria" State Arboretum of the National Academy of Sciences of Ukraine within the framework of the scientific theme "Restoration and reconstruction 
of historical flat-ravine type landscapes in the "Alexandria" State Arboretum of the National Academy of Sciences of Ukraine". The results of our research have shown affliction by illnesses and pests to be found on 331 exemplars (36.8\% of the total) of woody plants belonging to 19 species. The authors have detected a number of diseases and pests lesions of woody plants in the Eastern Ravine, which somehow harm the plants. The main diseases and pest infestations of the Fraxinus excelsior L., Acer platanoides L., Tilia cordata Mill., Acer campestre L., Robinia pseudoacacia L., Quercus robur L., Pinus sylvestris L. and other species of woody plants are described. The development of tree diseases and their phytosanitary state was determined mainly by the phytocoenotic conditions and the ecological conditions of the mesorelief. The majority of diseases of woody plants proceeded in the chronic form, not leading to the loss of trees decorativeness and to weaken of their viability. The closed frost cracks, small wounds of necrosis and cancerous diseases, mistletoe settlement, some tree-destroying mushrooms - with a slight lesions and small habitual displays, did not lead to drastic negative effects. The acute tone was caused of the bark beetle drying of pine with accompanying blue and drying of Fraxinus excelsior with a set of signs characteristic of the Chalara fraxinea disease. These lesions in the researched area lead to rapid massive drying of trees, and to decay of landscape compositions. Nowadays, this problem is global in its nature and there are no effective measures to combat these phytopathogens. While planning the optimization of the Eastern Ravine plantings, it is necessary to consider the phytopathological condition of the trees, to forecast their reduction and the formation of "windows", to take measures for individual treatment and care of trees, preventive and protective measures.

Keywords: restoration of landscape areas; diseases; pests; rapid drying; chronic drying. 